\title{
Molecular Typing of Cryptococcus neoformans: Taxonomic and Epidemiological Aspects
}

\author{
TEUN BOEKHOUT, ${ }^{1 *}$ ALEX VAN BELKUM, ${ }^{2}$ ALEXANDER C. A. P. LEENDERS, ${ }^{2}$ HENRI A. VERBRUGH, ${ }^{2}$ \\ PRISCA MUKAMURANGWA ${ }^{3}$ DANIELLE SWINNE, ${ }^{3}$ AND W. ALEXANDER SCHEFFERS ${ }^{4}$ \\ Yeast Division, Centraalbureau voor Schimmelcultures, 2628 BC Delft, ${ }^{1}$ Department of Bacteriology, \\ University Hospital Rotterdam, Rotterdam, ${ }^{2}$ and Department of Microbiology and Enzymology, Kluyver \\ Laboratory of Biotechnology, Delft University of Technology, Delft, ${ }^{4}$ The Netherlands, and \\ Laboratory of Mycology, Institute of Tropical Medicine, Antwerp, Belgium ${ }^{3}$
}

\begin{abstract}
Pulsed-field gel electrophoresis (PFGE), randomly amplified polymorphic DNA (RAPD) analysis, serotype, and killer toxin sensitivity patterns of a wide range of saprobic, clinical, and veterinary isolates of both varieties of Cryptococcus neoformans were examined. C. neoformans var. neoformans and C. neoformans var. gattii differed in chromosomal makeup, RAPD patterns, and killer sensitivity patterns. These results suggest that there are two separate species rather than two varieties. No clear genetic or phenotypic differences were observed among the clinical, saprobic, and veterinary isolates within each taxon. The serotypes differed substantially in their RAPD characteristics. Geographical clustering was observed among the isolates of $C$. neoformans var. gattii, but not among the isolates of $C$. neoformans var. neoformans. The isolates of each taxon that originated from restricted geographical areas often had identical or similar karyotypes and RAPD patterns, suggesting that clonal reproduction had occurred. The combination of PFGE and RAPD analysis allowed us to distinguish almost all isolates. This combination of techniques is recommended for further research on epidemiological, ecological, and population issues.
\end{abstract}

Cryptococcus neoformans (Sanfelice) Vuillemin is a zoopathogenic basidiomycetous yeast (teleomorph, Filobasidiella neoformans Kwon-Chung) which is usually encountered in the imperfect state. This fungus can cause serious infections, especially in immunocompromised patients. Estimates of the incidence rate in AIDS patients range from 5 to $30 \%$, with the highest numbers occurring in sub-Saharan Africa $(21,30)$. In human immunodeficiency virus-seropositive individuals, an infection with $C$. neoformans indicates progression to AIDS (40). The problem is aggravated by the emergence of cryptococcal strains that have become resistant to some of the most widely used antifungal agents $(11,19,33,34)$.

According to the current classification, $C$. neoformans consists of the following two varieties: $C$. neoformans var. neoformans, with serotypes A, D, and $\mathrm{AD}$ (teleomorph, $F$. neoformans var. neoformans), and $C$. neoformans var. gattii Vanbreuseghem et Takashio, with serotypes B and C (teleomorph, $F$. neoformans var. bacillispora Kwon-Chung) $(15,18,22,23,37)$. The occurrence of recombinants between strains of $C$. neoformans var. neoformans and $C$. neoformans var. gattii and the demonstration of genetic recombination in the F1 generation have suggested that these taxa are varieties $(25,41)$, but no genetic analysis of the F2 generation has been performed. In contrast, rather low DNA-DNA reassociation values (range, 55 to $63 \%$ ) (1) have been observed between isolates of the two varieties, which may reflect genetic divergence between the two taxa. The two varieties differ in karyotype (54), in a number of physiological characteristics (e.g., assimilation of D-proline, Dtryptophan, and L-malic acid), in regulation of creatinine deaminase by ammonia production $(2,13,31,38)$, and in sensitivity to killer toxins of Cryptococcus laurentii CBS 139 (3). The two varieties also differ in geographic distribution and

\footnotetext{
* Corresponding author. Mailing address: Yeast Division, Centraalbureau voor Schimmelcultures, Julianalaan 67, 2628 BC Delft, The Netherlands. Phone: 31-15-2782395. Fax: 31-15-2782355. E-mail: T. Boekhout@STM.TuDelft.nl.
}

habitat. C. neoformans var. neoformans occurs worldwide, whereas $C$. neoformans var. gattii is restricted to the tropics and the southern hemisphere. Both varieties originate from human and animal sources. In the environment, $C$. neoformans var. neoformans is frequently isolated from bird droppings and is occasionally isolated from substrates like fermenting fruit juice, wood, and air $(28,30,46)$. Saprobic isolates of $C$. neoformans var. gattii are usually associated with Eucalyptus species $(14,17,37,42)$, but have been isolated from bat guano as well (27). Differentiation between the varieties is usually performed on L-canavanine-glycine-bromthymol blue medium $(24,45)$ or by testing D-proline assimilation (13).

Nearly all of the AIDS-related C. neoformans infections are caused by $C$. neoformans var. neoformans, but the two varieties can cause similar neurological syndromes. To diagnose clinical infections and monitor dispersion of strains, technical instruments for cryptococcal genome scanning have been developed $(6,8,9,12,29,36,43,44,50,51)$. Molecular typing techniques have revealed that there is considerable genetic heterogeneity within the species $(51,54)$. PCR targeted at ribosomal operons has been used to identify the species accurately (53), but has provided insufficient resolution for epidemiological research. A major step forward was the discovery of a plasmid isolated from a URA 5 transformant of $C$. neoformans that could be used to detect genetic polymorphisms $(50,51)$. Additional probes have subsequently been developed (44), and simultaneous use of these probes gave results consistent with the $U R A$ plasmid analysis results, thus illustrating the validity of the two typing procedures. Analysis of randomly amplified polymorphic DNA (RAPD) has provided a genetic substructure for each variety $(6,8,43,56)$, but until now no comprehensive study has included both varieties.

In the present study the genetic diversity of the two varieties of $C$. neoformans, including a wide range of environmental and medical isolates, was analyzed by karyotyping and by performing a RAPD analysis with enterobacterial repetitive intergenic consensus (ERIC) primers $(48,52)$. In addition, serotypes and 
TABLE 1. Origins of the isolates of $C$. neoformans var. neoformans and $C$. neoformans var. gattii studied

\begin{tabular}{|c|c|c|c|c|c|}
\hline Strain $^{a}$ & Origin & Serotype & Mating type & Killer type ${ }^{b}$ & RAPD type \\
\hline \multicolumn{6}{|c|}{$\begin{array}{l}\text { C. neoformans var. neo- } \\
\text { formans strains }\end{array}$} \\
\hline CBS 131 & Institut Pasteur, Paris, France & $\mathrm{AD}$ & $?^{c}$ & IV & AA \\
\hline CBS $132^{T}$ & Fermenting fruit juice & $\mathrm{D}$ & $\alpha$ & II & AA \\
\hline CBS 464 & Laboratoire de Parasitologie, Paris, France & A & $?$ & IV & AA \\
\hline CBS 879 & Ulcerated cheek & A & $\alpha$ & II & BB \\
\hline CBS 880 & Unknown & A & $\alpha$ & II & $\mathrm{BC}$ \\
\hline CBS 881 & 36-Year-old woman & A & $\alpha$ & II & $\mathrm{BB}$ \\
\hline CBS $882^{\mathrm{T}}$ & Nasal tumor of horse, type strain of Torula nasalis Harrison & $\mathrm{D}$ & $\alpha$ & II & $\mathrm{CD}$ \\
\hline CBS 884 & Brain, The Netherlands & A & $\alpha$ & II & $\mathrm{BB}$ \\
\hline CBS 885 & Unknown & A & $\alpha$ & II & $\mathrm{BC}$ \\
\hline CBS 886 & Unknown & A & $\alpha$ & II & BB \\
\hline CBS 887 & Unknown & A & $\alpha$ & III & BB \\
\hline CBS 888 & Unknown & $\mathrm{D}$ & $\alpha$ & II & $\mathrm{CD}$ \\
\hline CBS 889 & Unknown & A & $?$ & III & $\mathrm{BE}$ \\
\hline CBS 916 & Unknown & A & $\alpha$ & II & $\mathrm{BE}$ \\
\hline CBS 918 & Dead white mouse & $\mathrm{D}$ & $\alpha$ & III & $\mathrm{CD}$ \\
\hline CBS 939 & Unknown & $\mathrm{AD}$ & $?$ & III & $\mathrm{AF}$ \\
\hline CBS 950 & Tumor & A & $?$ & III & $\mathrm{AF}$ \\
\hline CBS $996^{\mathrm{T}}$ & Blastomycosis in man, type strain of Candida psicrophylicus & A & $\alpha$ & III & BB \\
\hline CBS 1009 & Man & A & $\alpha$ & II & $\mathrm{BB}$ \\
\hline CBS 1143 & Cerebrospinal fluid & A & $\alpha$ & II & $\mathrm{BF}$ \\
\hline CBS 1144 & Cerebrospinal fluid & A & $\alpha$ & III & $\mathrm{BB}$ \\
\hline CBS 1584 & Unknown & A & $?$ & IV & $\mathrm{AF}$ \\
\hline CBS 1931 & Soil & A & $\alpha$ & II & BB \\
\hline CBS 1932 & Soil & A & $?$ & II & $\mathrm{BB}$ \\
\hline CBS 1933 & Mastitic cow, United States & A & $?$ & II & $\mathrm{BC}$ \\
\hline CBS 1935 & Soil & A & $\alpha$ & II & BB \\
\hline CBS 2771 & Cerebrospinal fluid & A & $\alpha$ & II & BB \\
\hline CBS 4194 & Spleen, Germany & $\mathrm{D}$ & $\alpha$ & II & $\mathrm{CB}$ \\
\hline CBS 4572 & Cerebrospinal fluid & A & $\alpha$ & II & BB \\
\hline CBS 4868 & Sputum, The Netherlands & A & $?$ & II & BB \\
\hline CBS 5467 & Milk from mastitic cow, Switzerland & $\mathrm{D}$ & $\alpha$ & III & $\mathrm{CD}$ \\
\hline CBS 5474 & Mastitic cow & $\mathrm{D}$ & $?$ & III & $\mathrm{CD}$ \\
\hline CBS 5728 & Nonmeningitic cellulitis and osteomyelitis, United States & $\mathrm{D}$ & $\alpha$ & II & $\mathrm{CD}$ \\
\hline CBS $6885^{\mathrm{T}}$ & Lesion on bone in man, type strain of Filobasidiella neoformans & $\mathrm{D}$ & $\alpha$ & II & $\mathrm{CD}$ \\
\hline CBS 6886 & Droppings of pigeon & $\mathrm{D}$ & $\mathrm{a}$ & II & $\mathrm{CD}$ \\
\hline CBS 6900 & Genetic offspring of CBS $6885 \times$ CBS 6886 & $\mathbf{D}$ & $\alpha$ & II & $\mathrm{CD}$ \\
\hline CBS 6901 & Genetic offspring of CBS $6885 \times$ CBS 6886 & $\mathrm{D}$ & a & III & $\mathrm{CD}$ \\
\hline CBS 6961 & Man, Oklahoma & A & $\alpha$ & II & $\mathrm{DE}$ \\
\hline CBS 6995 & Cerebrospinal fluid, Illinois & A & a & IV & $\mathrm{CD}$ \\
\hline CBS 6999 & Pigeon droppings, Thailand & A & $\alpha$ & II & BB \\
\hline CBS 7000 & Pigeon droppings, Denmark & $\mathrm{D}$ & $\mathrm{a}$ & III & $\mathrm{CD}$ \\
\hline CBS 7779 & Urease-negative isolate from AIDS patient, Argentina & A & $?$ & II & BB \\
\hline CBS 7812 & Cerebrospinal fluid & A & $?$ & 1 & $\mathrm{BC}$ \\
\hline CBS 7814 & Air, Belgium & $\mathrm{AD}$ & $\alpha$ & II & $\mathrm{CD}$ \\
\hline CBS 7815 & Pigeon droppings, former Czechoslovakia & $\mathrm{D}$ & $\alpha$ & II & $\mathrm{CD}$ \\
\hline CBS 7816 & Cuckoo droppings, Thailand & A & $\alpha a$ & II & CD \\
\hline RV 26952 & Cerebrospinal fluid, Zaire & A & $?$ & II & BB \\
\hline RV 46115 & Plants, India & A & $?$ & II & $\mathrm{BC}$ \\
\hline RV 46119 & Pigeon droppings, India & A & $?$ & II & BB \\
\hline RV 46129 & Pigeon droppings, India & A & $?$ & II & BB \\
\hline RV 52733 & Pigeon droppings, Belgium & $\mathrm{D}$ & $?$ & II & $\mathrm{AC}$ \\
\hline RV 52755 & Cerebrospinal fluid, Belgium & $\mathrm{AD}$ & $?$ & II & $\mathrm{AC}$ \\
\hline RV 53794 & Canary bird droppings, Belgium & $\mathrm{D}$ & $?$ & II & $\mathrm{AC}$ \\
\hline RV 55446 & House dust, Zaire & A & $?$ & II & BA \\
\hline RV 55447 & Air inside house, Zaire & A & $?$ & II & $\mathrm{BC}$ \\
\hline RV 55451 & Cockroach, Zaire & A & $?$ & III & $\mathrm{BC}$ \\
\hline RV 55980 & Canary bird droppings, Belgium & A & $?$ & II & BB \\
\hline RV 56126 & Cerebrospinal fluid from AIDS patient, Belgium (visited Haiti) & A & $?$ & II & GF \\
\hline RV 56883 & Canary bird droppings, Belgium & A & $?$ & II & $\mathrm{BB}$ \\
\hline RV 56894 & Canary bird droppings, Belgium & A & $?$ & II & BB \\
\hline RV 58145 & Wood, Zaire & A & $?$ & II & $\mathrm{BC}$ \\
\hline RV 58146 & Wood, Zaire & A & $?$ & II & EG \\
\hline RV 59351 & Parrot droppings, Belgium & A & $?$ & II & BA \\
\hline RV 59369 & Parrot droppings, Belgium & A & $?$ & II & BA \\
\hline RV 59379 & Air in zoo, Belgium & A & $?$ & II & BB \\
\hline RV 60047 & Skin cryptococcosis, Belgium & D & $?$ & II & $\mathrm{BC}$ \\
\hline RV 61756 & Man, Belgium (visited Zaire) & $\mathrm{AD}$ & $?$ & II & $\mathrm{AA}$ \\
\hline RV 61790 & Man, Belgium & A & $?$ & II & $\mathrm{BA}$ \\
\hline RV 62210 & Cerebrospinal fluid from AIDS patient, Belgium & A & $?$ & II & $\mathrm{BA}$ \\
\hline RV 62692 & Skin cryptococcosis, Belgium & $\mathrm{D}$ & $?$ & II & $\mathrm{CD}$ \\
\hline RV 63214 & Cerebrospinal fluid from AIDS patient, Zaire & A & $?$ & II & BB \\
\hline
\end{tabular}


TABLE $1-$ Continued

\begin{tabular}{|c|c|c|c|c|c|}
\hline Strain $^{a}$ & Origin & Serotype & Mating type & Killer type $^{b}$ & RAPD type \\
\hline RV 63642 & Cerebrospinal fluid from AIDS patient, Brazil & A & $?$ & II & BA \\
\hline RV 64610 & AIDS patient, Rwanda & A & $?$ & II & $\mathrm{CE}$ \\
\hline RV 64612 & AIDS patient, Rwanda & A & ? & II & BA \\
\hline RV 65631 & Cerebrospinal fluid, Zaire & A & ? & II & $\mathrm{BB}$ \\
\hline RV 65662 & Man, Portugal (visited Venezuela) & A & ? & II & $\mathrm{FC}$ \\
\hline RV 66025 & Cryptococcoma, Belgium & A & ? & II & $\mathrm{BC}$ \\
\hline RV 66055 & AIDS patient, Rwanda & A & ? & II & BA \\
\hline RDA 1335 & AIDS patient no. 1 , Rotterdam, The Netherlands & A & $?$ & II & BA \\
\hline RDA 1340 & AIDS patient no. 1 , Rotterdam, The Netherlands & A & $?$ & II & BA \\
\hline RDA 1371 & AIDS patient no. 2, Rotterdam, The Netherlands & A & $?$ & II & BA \\
\hline RDA 1369 & AIDS patient no. 3, Rotterdam, The Netherlands & A & $?$ & II & BA \\
\hline RDA 1373 & AIDS patient no. 3 , Rotterdam, The Netherlands & A & $?$ & II & BA \\
\hline RDA 1445 & AIDS patient no. 4, Rotterdam, The Netherlands & A & ? & II & $\mathrm{BA}$ \\
\hline RDA 1419 & AIDS patient no. 5, Rotterdam, The Netherlands & D & $?$ & I & FF \\
\hline RDA 1549 & AIDS patient no. 6 , Rotterdam, The Netherlands & A & $?$ & II & BA \\
\hline RDA 1589 & AIDS patient no. 7, Rotterdam, The Netherlands & A & $?$ & II & B- \\
\hline RDA 1006 & AIDS patient no. 8, Rotterdam, The Netherlands & A & $?$ & II & BA \\
\hline RDA 4092 & AIDS patient no. 9 , Rotterdam, The Netherlands & A & $?$ & II & BA \\
\hline RDA 4094 & AIDS patient no. 10 , Rotterdam, The Netherlands & A & ? & II & BA \\
\hline RDA 4054 & AIDS patient no. 11, Rotterdam, The Netherlands & A & $?$ & II & BA \\
\hline RDA 4091 & AIDS patient no. 12 , Rotterdam, The Netherlands & A & $?$ & II & BA \\
\hline \multicolumn{6}{|c|}{$\begin{array}{l}\text { C. neoformans var. gattii } \\
\text { strains }\end{array}$} \\
\hline CBS 883 & Infected skin, syntype of Candida hondurianus & B & $?$ & $\mathrm{~V}$ & GH \\
\hline CBS $919^{\mathrm{T}}$ & $\begin{array}{l}\text { Meningoencephalic lesion, type strain of Torulopsis neoformans } \\
\text { var. sheppei }\end{array}$ & B & $?$ & $\mathrm{~V}$ & GH \\
\hline CBS 1622 & Tumor & B & ? & $\mathrm{V}$ & GH \\
\hline CBS 1930 & Sick goat, Aruba & B & $?$ & VII & HI \\
\hline CBS 1934 & Mastitic cow, United States & B & ? & $\mathrm{V}$ & GJ \\
\hline CBS 2502 & Suspected case of tubercular meningitis & B & $?$ & $\mathrm{~V}$ & GJ \\
\hline CBS 5757 & Unknown & B & $\alpha$ & $\mathrm{V}$ & $\mathrm{GH}$ \\
\hline CBS 5758 & Unknown & $\mathrm{C}$ & $\alpha$ & VI & DK \\
\hline CBS 6289 & Subculture of type strain RV 20186 & B & a & VII & IJ \\
\hline CBS 6290 & Man, Republic of Congo & B & $?$ & $\mathrm{~V}$ & GJ \\
\hline CBS $6955^{\mathrm{T}}$ & Spinal fluid, type strain of Filobasidiella bacillispora, California & $\mathrm{C}$ & a & VI & DG \\
\hline CBS 6956 & Sputum, Washington & B & $\alpha$ & VIII & IN \\
\hline CBS 6992 & Man & B & $\alpha$ & $\mathrm{V}$ & $\mathrm{GH}$ \\
\hline CBS 6993 & Man, California & $\mathrm{C}$ & $\alpha$ & VI & DK \\
\hline CBS 6994 & Cerebrospinal fluid, New Jersey & $\mathrm{C}$ & $\alpha$ & IX & DG \\
\hline CBS 6996 & Man & B & $\alpha$ & VII & EL \\
\hline CBS 6997 & Cerebrospinal fluid, California & B & $\alpha$ & VI & DK \\
\hline CBS 6998 & Cerebrospinal fluid, Thailand & B & a & $\mathrm{X}$ & EM \\
\hline CBS $7229^{\mathrm{T}}$ & $\begin{array}{l}\text { Meningitis, type strain of } C \text {. neoformans var. shanghaiensis, } \\
\text { People's Republic of China }\end{array}$ & B & ? & $\mathrm{V}$ & GH \\
\hline CBS 7523 & Eucalyptus camaldulensis, Australia & B & $?$ & $\mathrm{~V}$ & GH \\
\hline CBS 7740 & Cerebrospinal fluid, Punjab, India & B & $?$ & VII & $\mathrm{GH}$ \\
\hline CBS 7741 & Cerebrospinal fluid, Punjab, India & B & $?$ & VII & $\mathrm{GH}$ \\
\hline CBS 7742 & Cerebrospinal fluid, Punjab, India & B & $?$ & VI & GH \\
\hline CBS 7747 & Seedling of olive, Australia & B & ? & $\mathrm{V}$ & $\mathrm{GH}$ \\
\hline CBS 7748 & Air in hollow Eucalyptus camaldulensis, Australia & B & ? & $\mathrm{V}$ & $\mathrm{GH}$ \\
\hline CBS 7749 & Bark of Eucalyptus camaldulensis, Australia & B & $?$ & $\mathrm{~V}$ & GH \\
\hline CBS 7750 & Bark debris of Eucalyptus camaldulensis, California & B & ? & VII & HI \\
\hline RV 5265 & Cerebrospinal fluid, Zaire & B & ? & $?$ & GJ \\
\hline RV $20186^{\mathrm{T}}$ & Cerebrospinal fluid, Zaire & B & a & VII & GJ \\
\hline RV 54130 & Second isolate of $C$. neoformans var. shanghaiensis & B & ? & VI & GJ \\
\hline RV 66095 & Cerebrospinal fluid, Brazil & B & ? & $\mathrm{X}$ & GJ \\
\hline ATCC 32269 & Subculture of type strain of $C$. gattii & B & a & ? & GJ \\
\hline NIH B-3939 & Subculture of type strain of $C$. gattii & B & a & ? & GJ \\
\hline
\end{tabular}

${ }^{a}$ CBS, Centraalbureau voor Schimmelcultures Yeast Division; RV, Institute of Tropical Medicine; NIH, National Institutes of Health; ATCC, American Type Culture Collection.

${ }^{b}$ Killer sensitivity types as described by Boekhout and Scorzetti (3).

c?, not known.

killer toxin sensitivity patterns were analyzed, and epidemiological features are discussed below.

\section{MATERIALS AND METHODS}

Fungal strains. Medical and saprobic isolates of $C$. neoformans var. neoformans and $C$. neoformans var. gattii were obtained from the collections of the Yeast Division, Centraalbureau voor Schimmelcultures (Delft, The Netherlands), the Laboratory of Mycology, Institute of Tropical Medicine (Antwerp,
Belgium), the Department of Bacteriology, University Hospital Rotterdam (Rotterdam, The Netherlands), and D. Ellis (Adelaide, Australia). Additional isolates were obtained from the National Institutes of Health (Bethesda, Md.) and the American Type Culture Collection (Rockville, Md.). The varieties to which the strains belonged were confirmed by performing color reaction tests on L-canavanine-glycine-bromthymol blue medium, D-proline assimilation tests, and kille toxin sensitivity tests. A total of 92 C. neoformans var. neoformans strains and 32 C. neoformans var. gattii strains were studied (Table 1). The strains were maintained on $1 \%$ yeast extract $-0.5 \%$ peptone $-4 \%$ glucose agar slants at $10^{\circ} \mathrm{C}$. 
TABLE 2. Distribution of serological types in clinical, saprobic, and veterinary isolates of $C$. neoformans var. neoformans and $C$. neoformans var. gattii

\begin{tabular}{|c|c|c|c|c|c|c|c|}
\hline \multirow{3}{*}{ Type of isolates } & \multicolumn{4}{|c|}{ C. neoformans var. neoformans } & \multicolumn{3}{|c|}{ C. neoformans var. gattii } \\
\hline & \multirow{2}{*}{ No. of isolates } & \multicolumn{3}{|c|}{$\%$ of isolates that are: } & \multirow{2}{*}{ No. of isolates } & \multicolumn{2}{|c|}{$\%$ of isolates that are: } \\
\hline & & Serotype A & Serotype D & Serotype AD & & Serotype B & Serotype C \\
\hline Saprobic & 25 & 72 & 24 & 4 & 5 & 100 & 0 \\
\hline Clinical & 34 & 83 & 13 & 4 & 19 & 85 & 15 \\
\hline Veterinary & 5 & 20 & 80 & 0 & 2 & 100 & 0 \\
\hline Other & 1 & 100 & 0 & 0 & 0 & 0 & 0 \\
\hline
\end{tabular}

Serotyping. The antigens used for production of antisera were prepared from the following strains: RV 56164 (serotype A), isolated from canary bird droppings in Belgium; RV 68038 (serotype D), isolated from wood in Burundi; RV 20185 (= ATCC 32267) (serotype B); and RV 45978 (= ATCC 34880) (serotype C). Polyclonal antisera were raised by immunizing female New Zealand White rabbits with heat-killed $C$. neoformans cells. The antisera used for final serotypin in a slide agglutination test were first adsorbed with a mixture of cells of the other serotypes by using the method described by Wilson et al. (55).

Killer toxin sensitivity. Killer toxin sensitivity was analyzed by using protocols described elsewhere (3). The following killer strains were used: $C$. laurentil (Kufferath) Skinner CBS 139, CBS 7235, and CBS 7857; Cryptococcus podzolicus (Bab'eva et Reshetova) Golubev CBS 7717; Cryptococcus humicola (Daszewska) Golubev CBS 4281; and Filobasidium capsuligenum Rodrigues de Miranda CBS 4736. Ten sensitivity types were discerned (3).

PFGE analysis. The cells used for pulsed-field gel electrophoresis (PFGE) were grown in $1 \%$ yeast extract $-0.5 \%$ peptone $-4 \%$ glucose broth at $25^{\circ} \mathrm{C}$ with shaking at $180 \mathrm{rpm}$. Agarose plugs were prepared as described by De Jonge et al. (10) by using Novozym 234 (Novo Industri AS, Bagsvaerd, Denmark). Electrophoresis was performed in a contour-clamped homogeneous electric field (CHEF) DR-II apparatus (Bio-Rad, Veenendaal, The Netherlands) by using the following conditions: $30 \mathrm{~h}$ with a ramping pulse time from 100 to $300 \mathrm{~s}$, followed by $40 \mathrm{~h}$ with a ramping pulse time from 400 to $600 \mathrm{~s}$. Initially, $110 \mathrm{~V}$ was applied but during later experiments $100 \mathrm{~V}$ was applied. Gels were made with chromosome grade agarose (Bio-Rad) in $0.5 \times \mathrm{TBE}$ and were electrophoresed at $12^{\circ} \mathrm{C}$ Commercially available plugs of Saccharomyces cerevisiae and Hansenula winge (= Pichia canadensis) (both obtained from Bio-Rad) were used as molecular size standards. After electrophoresis was completed, the gels were stained with $0.5 \mu \mathrm{g}$ of ethidium bromide per $\mathrm{ml}$ for $30 \mathrm{~min}$, destained with distilled water for $30 \mathrm{~min}$ and photographed with a UV transilluminator at $300 \mathrm{~nm}$. The sizes of chromosomes were calculated by comparing the running distances with a plot of running distance versus chromosome size for the standards. Karyotypes were also compared by using the program Gelcompar (Applied Maths, Ghent, Belgium).

RAPD analysis. DNA for the RAPD analysis was isolated from colonies grown for 2 or 3 days on solid Sabouraud medium at $30^{\circ} \mathrm{C}$. Cells were harvested by suspending them in $1 \mathrm{ml}$ of $20 \mathrm{mM}$ sodium citrate $(\mathrm{pH} 5.8)-1 \mathrm{M}$ sorbitol containing $10 \mathrm{mg}$ of Novozym $234 \mathrm{per} \mathrm{ml}$. The suspension was incubated at $37^{\circ} \mathrm{C}$ for $2 \mathrm{~h}$, and spheroplasts were collected by centrifugation. DNA was isolated by lysing the spheroplasts in guanidinium isothiocyanate-containing buffers, and this was followed by affinity purification with Celite (Acros, Geel, Belgium) (4). DNA was dissolved in $10 \mathrm{mM}$ Tris- $\mathrm{HCl}(\mathrm{pH} 8.0)-1 \mathrm{mM}$ EDTA and stored at $-20^{\circ} \mathrm{C}$
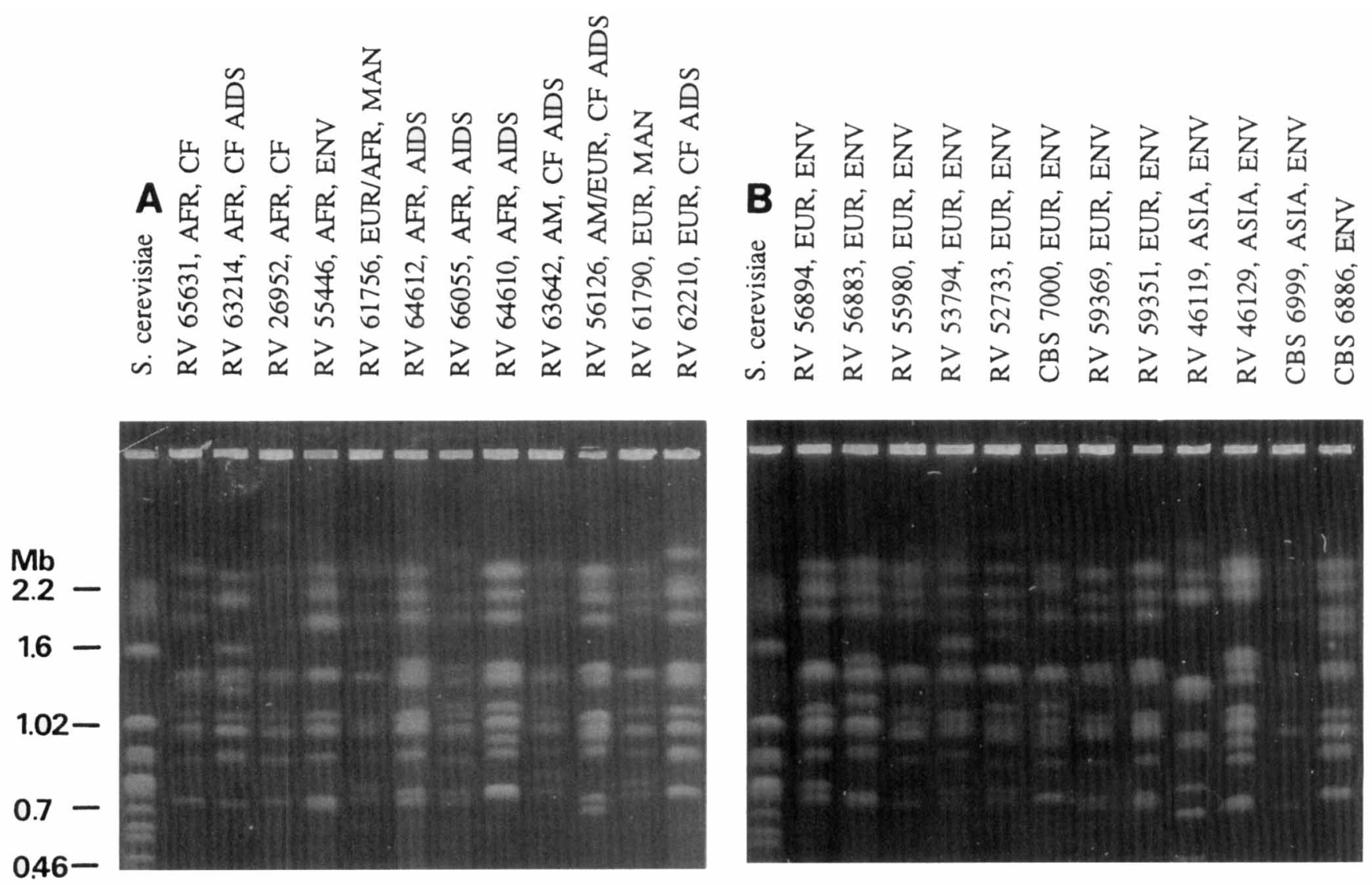

FIG. 1. Karyotypes of strains of $C$. neoformans var. neoformans. (A) Clinical isolates. (B) Environmental isolates. Abbreviations: AFR, Africa; EUR, Europe; AM, America; CF, cerebrospinal fluid; ENV, environmental. S. cerevisiae was the standard used. 

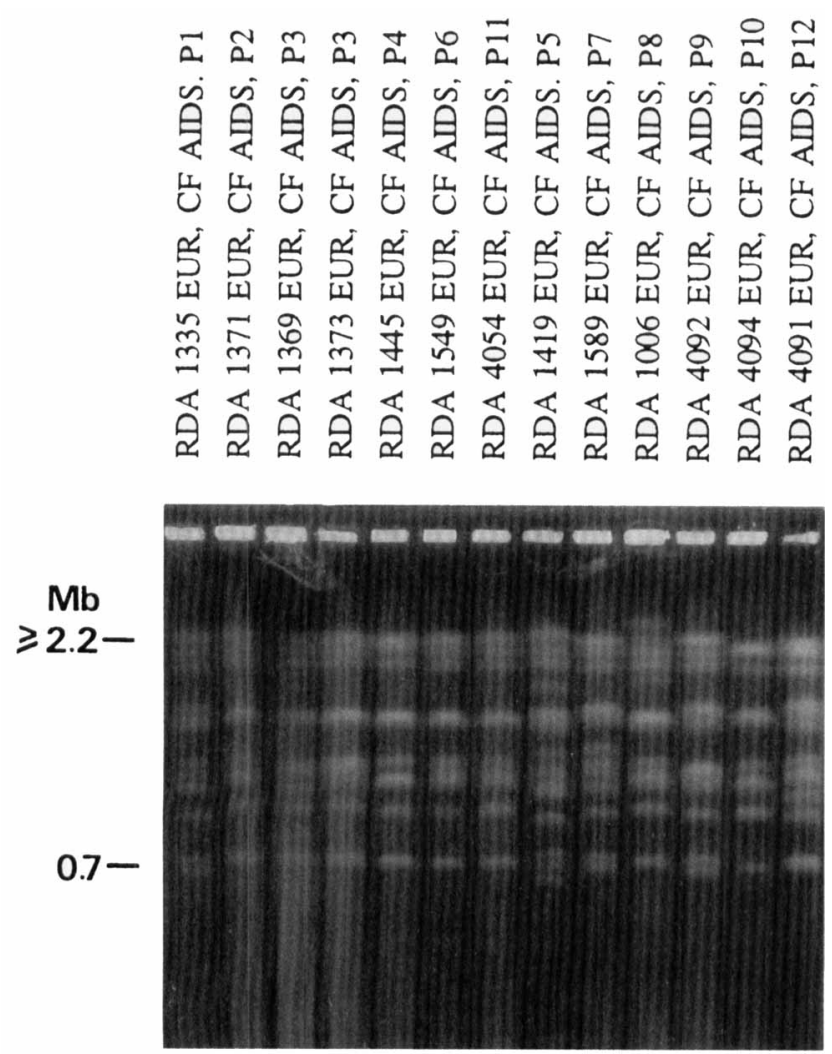

FIG. 2. Karyotypes of isolates of $C$. neoformans var. neoformans from Rotterdam AIDS patients. Abbreviations: CF, cerebrospinal fluid; P, patient; EUR, Europe.

Concentrations were determined by comparing the ethidium bromide staining intensities of aliquots with the staining intensities of known amounts of bacteriophage lambda DNA. The RAPD analysis was performed by using the following cycling parameters: predenaturation at $94^{\circ} \mathrm{C}$ for $4 \mathrm{~min}$, followed by 35 cycles consisting of $1 \mathrm{~min} 94^{\circ} \mathrm{C}, 1 \min 25^{\circ} \mathrm{C}$, and $2 \min 74^{\circ} \mathrm{C}(20,48)$. Approximately 50 ng of DNA was amplified by using primers ERIC1 and ERIC2 (50 pmol in 100 $\mu l)$. The DNA band patterns obtained with these two primers were inspected visually and were designated by using uppercase letters. If the patterns obtained with the same primer differed in more than two bands, a novel type was defined.

\section{RESULTS}

Serotyping. The serotype data are listed in Table 1. A serological comparison of the clinical, veterinary, and saprobic isolates (Table 2) showed that most of the clinical and saprobic isolates of $C$. neoformans var. neoformans were serotype A organisms, but four of the five veterinary isolates were serotype $\mathrm{D}$ organisms. All of the saprobic and veterinary isolates and most of the clinical isolates of $C$. neoformans var. gattii were serotype B organisms.

Killer sensitivity. The killer sensitivity data are shown in Table 1 . The two varieties had different killer sensitivity patterns. Isolates of $C$. neoformans var. neoformans belonged to killer sensitivity types I to IV. About $80 \%$ of these organisms were type II organisms, $13 \%$ were type III organisms, $4 \%$ were type IV organisms, and $2 \%$ were not sensitive at all (type I). No clear relationship among serotype, source of isolation, and geography was observed. About $43 \%$ of the $C$. neoformans var. gattii isolates were killer sensitivity type V organisms, $23 \%$ were type VII organisms, 20\% were type VI organisms, $7 \%$ were type $\mathrm{X}$ organisms, $3 \%$ were type VIII organisms, and $3 \%$ were type IX organisms. All six of these six killer sensitivity types were represented by the American isolates studied. The
African and Asian populations contained fewer killer sensitivity types, and in the Australian population only one type (type V) was identified. The only California isolate studied from Eucalyptus sp. was a type VII organism.

Karyotyping by PFGE. The karyotype analysis revealed considerable heterogeneity among the isolates (Fig. 1 through 4). Most isolates of $C$. neoformans var. neoformans, whether they were clinical, veterinary, or saprobic, produced a variety of band patterns; these patterns usually consisted of 11 to 13 bands, but the patterns contained between 9 and 21 bands (Fig. 1,2 , and 4 and Table 3 ). The sizes of the individual chromosomes usually ranged between ca. 0.7 and $2.7 \mathrm{Mb}$, but in some isolates (e.g., CBS $132^{\mathrm{T}}$ [T = type strain], CBS 464, CBS 916, CBS 5467, and RV 26952) a larger chromosome ( $\geq 3.1 \mathrm{Mb}$ ) was present (Fig. 1 and 4). In some isolates a smaller chromosome was present; e.g., RV 46119 had a ca. 500-kb chromosome, CBS 950 had a ca. 600-kb chromosome, CBS 464 had a ca. 370-kb chromosome, CBS 916 had a ca. 300-kb chromosome, and RV 52755 had a ca. 520-kb chromosome. No consistent differences were apparent among the clinical, veterinary, and saprobic isolates or among the serotype A, D, and $\mathrm{AD}$ isolates. The overall patterns consisted of four or five to eight or nine bands between ca. 0.7 and $1.4 \mathrm{Mb}$, frequently with a doublet or triplet at ca. 1 and $1.4 \mathrm{Mb}$, and three or four bands between 1.8 and $2.7 \mathrm{Mb}$. A number of isolates contained a more or less continuous series of chromosomes. This was the case in CBS 132, the type strain of $C$. neoformans var. neoformans, and in CBS 464 and RV 52755 (Fig. 4). The genome sizes of selected isolates of $C$. neoformans var. neoformans that had no or a few doublet chromosomes varied between 15 and $27 \mathrm{Mb}$ (Table 4).

The lengths of the chromosomes of $C$. neoformans var. gattii isolates usually varied between ca. $500 \mathrm{~kb}$ and $2.7 \mathrm{Mb}$ (Fig. 3 and 4 ), and the number of chromosomes ranged from 10 to 14 (Table 3). In some isolates (e.g., CBS 919 and CBS 6289) a larger chromosome ( $\geq 3.1 \mathrm{Mb}$ ) was present (Fig. 3 and 4$)$. The sizes of the smallest chromosomes of most $C$. neoformans var. gattii isolates were estimated to vary between ca. 0.5 and 0.6 $\mathrm{Mb}$; the only exception was CBS 6998, whose lowermost band was at ca. $0.75 \mathrm{Mb}$ (data not shown). The overall patterns contained ca. six or seven bands between ca. 0.5 and $1.4 \mathrm{Mb}$, with a doublet (or triplet) at ca. $1.4 \mathrm{Mb}$, and two or three bands between ca. 2.0 and $2.4 \mathrm{Mb}$. All of the serotype Cisolates (CBS 5758, CBS 6993, CBS 6994, and CBS 6955) had an additional band at $1.8 \mathrm{Mb}$, which was present in only one serotype $\mathrm{B}$ isolate (CBS 6997). The genome sizes of $C$. neoformans var. gattii strains were on average smaller than the genome sizes of C. neoformans var. neoformans strains (Table 4). Estimates of sizes based solely on isolates that had no or a few doublet chromosomes varied between ca. 12 and $18 \mathrm{Mb}$.

No differentiation was observed between clinical and saprobic isolates. Three main clusters were identified after a cluster analysis performed with the unweighted pair group method using arithmetic averages (Fig. 5). Cluster 1 contained some of the American isolates, as well as a Chinese isolate; cluster 2 contained Australian, African, and Indian isolates; and cluster 3 contained only American isolates. The saprobic strains from Australia (cluster 2) had similar karyotypes and identical RAPD types. The karyotypes and RAPD patterns of three medical isolates from India (cluster 2) were identical. Also, the karyotypes and RAPD patterns of two meningitis isolates (CBS 7229 and RV 54130) from the People's Republic of China and clinical isolate CBS 919 from the United States were similar.

The karyotypes of type strain RV 20186 of $C$. neoformans var. gattii and its subcultures stored in different culture collec- 


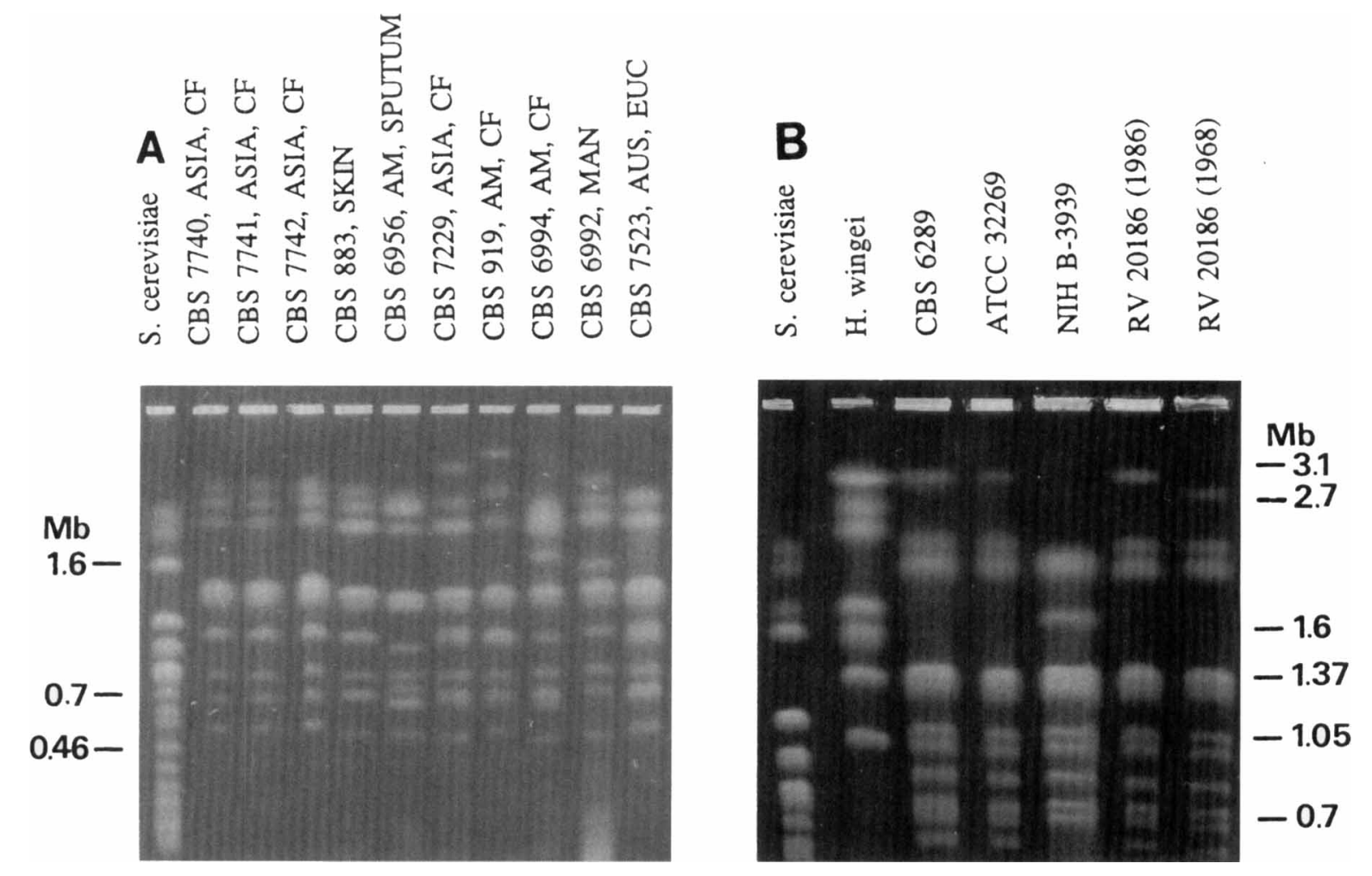

FIG. 3. Karyotypes of selected strains of $C$. neoformans var. gattii. (A) Karyotypes of medical and environmental isolates. (B) Karyotypes of subcultures of the type strain of $C$. neoformans var. gattii from different culture collections. Abbreviations: ATCC, American Type Culture Collection; CBS, Centraalbureau voor Schimmelcultures; NIH, National Institutes of Health; RV, Institute of Tropical Medicine; CF, cerebrospinal fluid; AM, America; AUS, Australia; EUC, Eucalyptus. S. cerevisiae and $H$. winge $i$ were the standards used.

GATTII

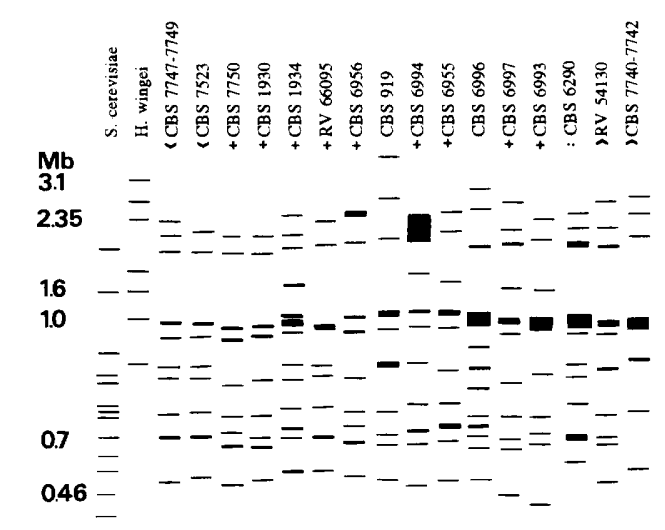

CLINICAL
NEOFORMANS

ENVIRONMENTAL

ANIMAL

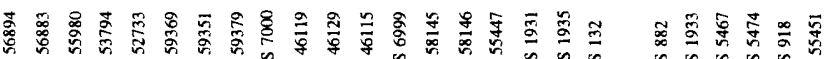

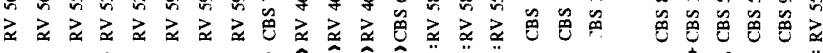

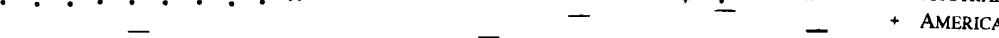

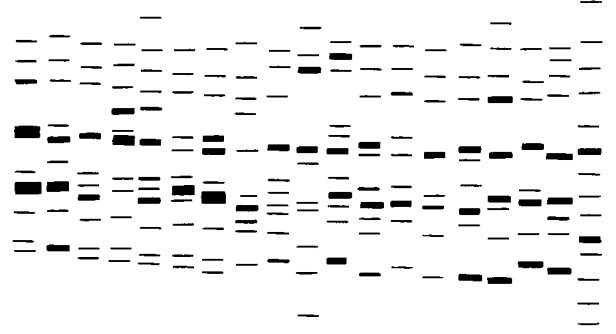

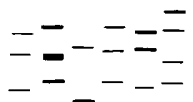

- ASIA

.. AFrICA

- EUROPE

NEOFORMANS
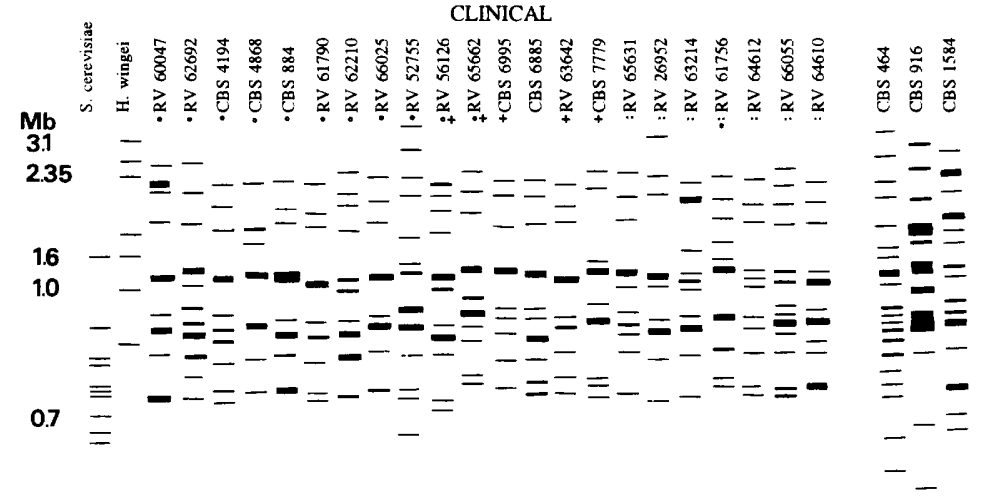

ROTTERDAM AIDS

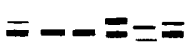

ーミニニニミ - ニ =ニ-

FIG. 4. Schematic representation of karyotypes of $C$. neoformans. (S. cerevisiae and $P$. canadensis were the standards used.) 
TABLE 3. Distribution of chromosome numbers among isolates of $C$. neoformans var. neoformans and $C$. neoformans var. gattil

\begin{tabular}{ccccc}
\hline $\begin{array}{c}\text { No. of } \\
\text { chromosomal } \\
\text { DNA bands }\end{array}$ & \multicolumn{3}{c}{$\begin{array}{c}\text { \% of } C \text {. neoformans var. } \\
\text { neoformans isolates }\end{array}$} & $\begin{array}{c}\text { \% of } C \text {. neoformans } \\
\text { var. gattii isolates } \\
(n=25)\end{array}$ \\
\cline { 2 - 4 } & $\begin{array}{c}\text { Clinical } \\
(n=55)\end{array}$ & $\begin{array}{c}\text { Veterinary } \\
(n=5)\end{array}$ & $\begin{array}{c}\text { Saprobic } \\
(n=20)\end{array}$ & \\
\hline 9 & 4 & & & \\
10 & 7 & & 10 & 20 \\
11 & 22 & & 20 & 8 \\
12 & 29 & 20 & 35 & 20 \\
13 & 15 & 20 & 20 & 40 \\
14 & 9 & 40 & 5 & 12 \\
15 & 7 & 20 & 5 & \\
16 & 2 & & 5 & \\
17 & & & & \\
18 & & & & \\
19 & 2 & & & \\
20 & 2 & & & \\
21 & 2 & & & \\
\hline
\end{tabular}

tions (CBS 6289 and ATCC 32269) were identical, whereas subculture NIH B-3939 differed in a number of bands. The latter strain lacked the upper and lower bands and had an additional band at ca. $1.8 \mathrm{Mb}$ (Fig. 3). The largest chromosome of isolate RV $20186^{\mathrm{T}}$, which was lyophilized shortly after its discovery in 1968, was found to be somewhat smaller than the largest chromosome of a subculture lyophilized in 1986 after multiple rounds of cultivation on agar slants.

RAPD analysis. Figure 6 shows some of the experimental data obtained when DNA amplification with primers ERIC1 and ERIC2 was performed. The band patterns of the varieties differed. The complete data set obtained with ERIC1 and ERIC2 is presented and interpreted in Table 1. Sixteen different genotypes occurred in $C$. neoformans var. neoformans, resulting in an index of variation (i.v.) of $16 / 91=17.5$. However, $83 \%$ of the $C$. neoformans var. neoformans strains belonged to
TABLE 4. Estimated genome sizes of selected isolates of C. neoformans

\begin{tabular}{clc}
\hline Taxon & Strain & $\begin{array}{c}\text { Estimated genome } \\
\text { size (Mb) }\end{array}$ \\
\hline C. neoformans var. neoformans & CBS 464 & 27 \\
& CBS 918 & 19 \\
& CBS 6885 & 19 \\
& CBS 7779 & 15 \\
& RV 52755 & 22 \\
& RV 59379 & 18.5 \\
& RV 61756 & 20 \\
C. neoformans var. gattii & CBS 883 & 17 \\
& CBS 919 & 16.5 \\
& CBS 1930 & 15 \\
& CBS 6289 & 18 \\
& CBS 6955 & 16 \\
& CBS 6992 & 16 \\
& CBS 6993 & 16 \\
& CBS 6996 & 16 \\
& CBS 6997 & 18 \\
& CBS 7229 & 17 \\
& CBS 7748 & 15 \\
& CBS 7750 & 14 \\
& RV 54130 & 17 \\
& RV 66095 & 12 \\
\hline
\end{tabular}

only nine genotypes, which resulted in an i.v. of 11. Eight different genotypes occurred in $C$. neoformans var. gattii, resulting in an i.v. of $8 / 30=27$. However, $77 \%$ of the strains of C. neoformans var. gattii belonged to only three genotypes (i.v., 13).

Comparisons of genotypes and serotypes, origins, and geographical distribution are presented in Tables 5 through 7 . No clear differences among the clinical, saprobic, and veterinary strains were apparent (Table 5). The largest number of RAPD types occurred among strains of clinical origin, but the differences in the i.v.'s appeared to be insignificant. Four of the five

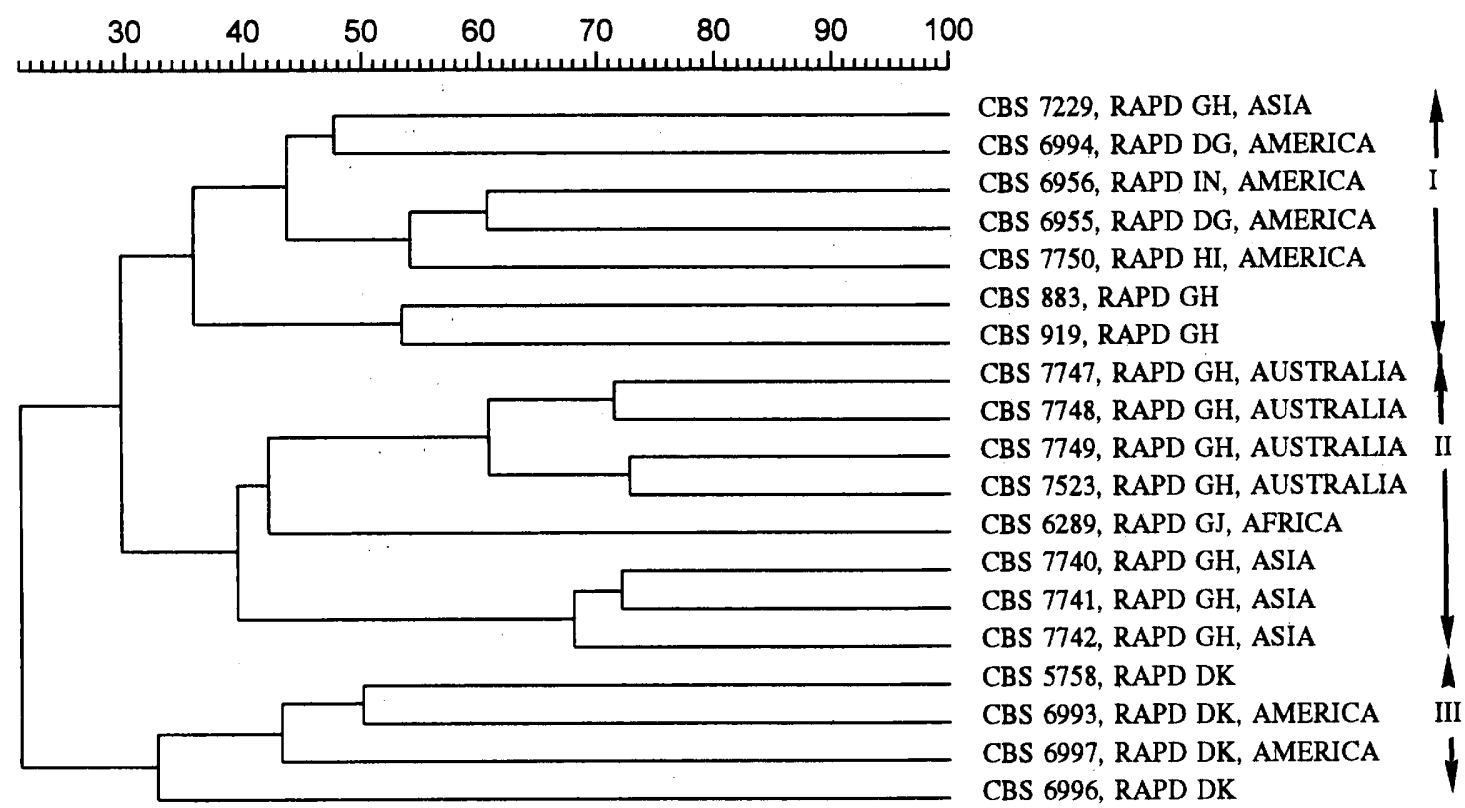

FIG. 5. Unweighted pair group with arithmetic average clustering of karyotypes of $C$. neoformans var. gattii and correlation with RAPD types. There are three main clusters (clusters I, II, and III), which correlate well with the RAPD types. 


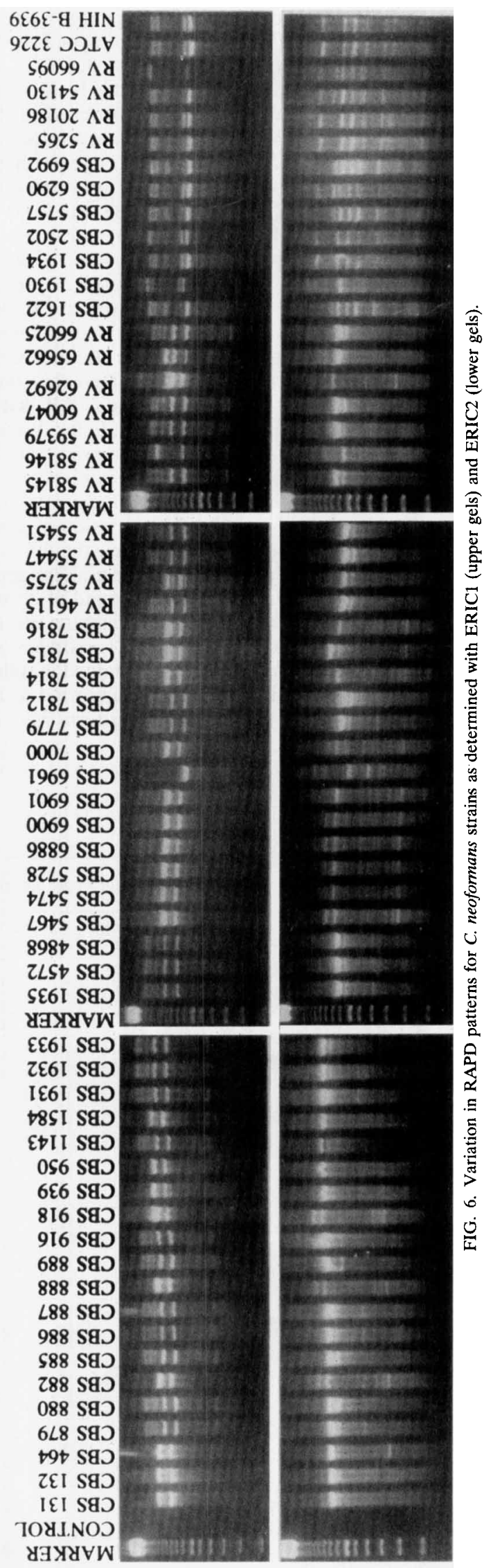

TABLE 5. Distribution of RAPD types among clinical, saprobic, and veterinary isolates of $C$. neoformans

\begin{tabular}{|c|c|c|c|c|}
\hline \multirow{2}{*}{$\begin{array}{l}\text { Type of } \\
\text { isolates }\end{array}$} & \multicolumn{2}{|c|}{$\begin{array}{l}\text { C. neoformans } \\
\text { var. neoformans }\end{array}$} & \multicolumn{2}{|c|}{$\begin{array}{l}\text { C. neoformans } \\
\text { var. gattii }\end{array}$} \\
\hline & RAPD type & No. of strains & RAPD type & No. of strains \\
\hline \multirow[t]{14}{*}{ Clinical } & BA & 17 & $\mathrm{GH}$ & 7 \\
\hline & BB & 13 & GJ & 6 \\
\hline & $\mathrm{CD}$ & 4 & DG & 2 \\
\hline & $\mathrm{BC}$ & 3 & DK & 2 \\
\hline & AA & 1 & EL & 1 \\
\hline & $\mathrm{AC}$ & 1 & EM & 1 \\
\hline & $\mathrm{AF}$ & 1 & IN & 1 \\
\hline & $\mathrm{BF}$ & 1 & & \\
\hline & $\mathrm{CB}$ & 1 & & \\
\hline & $\mathrm{CE}$ & 1 & & \\
\hline & $\mathrm{DE}$ & 1 & & \\
\hline & FC & 1 & & \\
\hline & $\mathrm{FF}$ & 1 & & \\
\hline & GF & 1 & & \\
\hline \multirow[t]{7}{*}{ Saprobic } & BB & 10 & GH & 4 \\
\hline & $\mathrm{CD}$ & 5 & $\mathrm{HI}$ & 1 \\
\hline & $\mathrm{BC}$ & 4 & & \\
\hline & $\mathrm{BA}$ & 3 & & \\
\hline & $\mathrm{AC}$ & 2 & & \\
\hline & AA & 1 & & \\
\hline & EG & 1 & & \\
\hline \multirow[t]{2}{*}{ Veterinary } & $\mathrm{CD}$ & 4 & $\mathrm{HI}$ & 1 \\
\hline & $\mathrm{BC}$ & 1 & GJ & 1 \\
\hline
\end{tabular}

veterinary isolates of C. neoformans var. neoformans (80\%) were RAPD type CD organisms, and $80 \%$ of the isolates from AIDS patients were type BA organisms. Most of the serotype B strains differed from the serotype $C$ strains; the only exception was one RAPD type DK strain (Table 6). About $70 \%$ of the serotype D strains (13 of 19 strains) were genotype CD organisms, but only $3 \%$ of the serotype A strains (2 of 65 strains) were genotype $\mathrm{CD}$ organisms. Strains of $C$. neoformans var. neoformans that originated from different continents did not differ widely in genetic structure, whereas the strains of $C$. neoformans var. gattii exhibited a geographic substructure (Table 7). The single Australian RAPD type, type GH, also occurred in Asia, but was absent in Africa and the Americas. The Asian, African, and American populations were linked by RAPD type GJ. About $80 \%$ of the American isolates (seven of nine isolates) exhibited RAPD types (types DG, DK, HI, and IN) that did not occur on the other continents.

Local isolates from AIDS patients. The Rotterdam isolates from AIDS patients had rather homogeneous karyotypes and RAPD types (Fig. 2 and 4 and Table 1). All of the strains except RDA 1419 were RAPD type BA organisms. Isolate RDA 1419 also differed in its karyotype, its serotype (serotype D), and its killer type (type I) (Table 1). Two isolates obtained from the same patient (RDA 1335 and RDA 1340) had identical karyotypes and RAPD types. However, the karyotypes of two isolates from another patient (RDA 1369 and RDA 1373) differed slightly in the penultimate band (Fig. 2). Two series of isolates (isolates RDA 1371, RDA 1373, RDA 1549, and RDA 4054 and isolates RDA 1445 and RDA 4094) could not be differentiated by the combination of karyotyping and RAPD typing. PFGE revealed more genetic heterogeneity among the Rotterdam isolates than RAPD typing revealed. 
TABLE 6. Distribution of RAPD types among serotypes of C. neoformans

\begin{tabular}{|c|c|c|}
\hline Serotype & RAPD type & No. of strains \\
\hline A & $\mathrm{BB}$ & 23 \\
\hline A & BA & 20 \\
\hline A & $\mathrm{BC}$ & 9 \\
\hline A & $\mathrm{AF}$ & 2 \\
\hline A & $\mathrm{BE}$ & 2 \\
\hline A & $\mathrm{CD}$ & 2 \\
\hline A & $\mathrm{AA}$ & 1 \\
\hline A & $\mathrm{BF}$ & 1 \\
\hline A & $\mathrm{CE}$ & 1 \\
\hline A & DE & 1 \\
\hline A & $\mathrm{EG}$ & 1 \\
\hline A & $\mathrm{FC}$ & 1 \\
\hline A & GF & 1 \\
\hline $\mathrm{D}$ & $\mathrm{CD}$ & 13 \\
\hline D & $\mathrm{AC}$ & 2 \\
\hline D & $\mathrm{AA}$ & 1 \\
\hline $\mathrm{D}$ & $\mathrm{BC}$ & 1 \\
\hline D & CB & 1 \\
\hline $\mathrm{D}$ & $\mathrm{FF}$ & 1 \\
\hline $\mathrm{AD}$ & $\mathrm{AA}$ & 2 \\
\hline $\mathrm{AD}$ & $\mathrm{AC}$ & 1 \\
\hline $\mathrm{AD}$ & $\mathrm{AF}$ & 1 \\
\hline $\mathrm{AD}$ & $\mathrm{CD}$ & 1 \\
\hline B & $\mathrm{GH}$ & 12 \\
\hline $\mathrm{B}$ & GJ & 7 \\
\hline B & HI & 2 \\
\hline B & DK & 1 \\
\hline B & EL & 1 \\
\hline B & EM & 1 \\
\hline B & IN & 1 \\
\hline $\mathrm{C}$ & DK & 2 \\
\hline $\mathrm{C}$ & DG & 2 \\
\hline
\end{tabular}

\section{DISCUSSION}

Recently, pulsed-field techniques, DNA fingerprinting, and PCR-mediated procedures have been used to detect genetic variation in $C$. neoformans $(5,6,8,9,12,26,36,43,51,54,56)$. In these studies usually a limited number of isolates (e.g., isolates originating from a restricted geographic area or isolates belonging to only one of the varieties) have been studied.

The observed differences in genetic makeup, mycotoxin sensitivity patterns, and serology between the two varieties bring into question the conspecific status of these taxa. If the two entities interbreed, we do not understand how the genetic differences are maintained, as homogenization of the population would be expected. However, if reproduction is clonal, as suggested previously (6), the presence of mutually exclusive genetic patterns suggests that different species are involved. Therefore, because of intermediate DNA-DNA hybridization values (1), we have concluded that two separate species may be involved. If this turns out to be true, the binomials Cryptococcus bacillisporus Kwon-Chung et Bennett (synonym, C. neoformans var. gattii Vanbreuseghem et Takashio) and Filobasidiella bacillispora Kwon-Chung should be used for the second taxon in its anamorphic and teleomorphic stages, respectively.

Karyotype analysis has revealed strain-specific band patterns $(12,36)$. Groups of strains with similar or identical karyotypes usually have identical RAPD types. The first analysis of the $C$. neoformans genome revealed 12 or 13 chromosomes in the type strain of $C$. neoformans var. neoformans, CBS 132 (10). Somewhat later, three different karyotype patterns were observed (one for serotype A isolates, one for serotype D isolates, and one for serotype B or C isolates) (39). Perfect et al. (35), however, found considerable variation in the band patterns within all four serotypes. Wickes et al. (54) observed differences between the karyotypes of $C$. neoformans var. gattii and $C$. neoformans var. neoformans, and this was largely confirmed by our results. However, some isolates of $C$. neoformans var. neoformans (e.g., CBS $132^{\mathrm{T}}$, CBS 464, CBS 916, and CBS 1584) contained smaller chromosomes (up to ca. $0.3 \mathrm{Mb}$ ), which fell into the size range of $C$. neoformans var. gattii chromosomes. When used with caution, karyotypes may provide estimates of genome size. A serious problem in estimating genome sizes on the basis of karyotypes is that comigrating bands may occur, and different estimates are used for individual chromosomes. Perfect et al. (35) estimated that the genome size of $C$. neoformans is between 15 and $17 \mathrm{Mb}$, with the number of bands ranging between 10 and 12 . Later, Wickes et al. (54) calculated considerably larger genome sizes, ca. 21 to $24.5 \mathrm{Mb}$, with 13 chromosomes on average in C. neoformans var. gattii and 12 chromosomes in C. neoformans var. neoformans. Our results revealed considerable variation in genome size in both varieties, suggesting that there may be differences in ploidy and/or aneuploidy within the species. The genome size of $C$. neoformans var. neoformans was found to be somewhat larger than the genome size of $C$. neoformans var. gattii.

We observed some differences among the karyotypes of the type strains of $C$. neoformans var. gattii maintained in different culture collections. These differences were supported by DNA fingerprinting results (21a), but our RAPD patterns were iden-

TABLE 7. Geographic distribution of RAPD types of $C$. neoformans

\begin{tabular}{|c|c|c|c|c|}
\hline \multirow{2}{*}{ Location } & \multicolumn{2}{|c|}{$\begin{array}{l}\text { C. neoformans var. } \\
\text { neoformans }\end{array}$} & \multicolumn{2}{|c|}{ C. neoformans var. gattii } \\
\hline & RAPD type & No. of strains & RAPD type & No. of strains \\
\hline \multirow[t]{5}{*}{ America } & $C D$ & 3 & GJ & 2 \\
\hline & $\mathrm{BA}$ & 1 & DG & 2 \\
\hline & BB & 1 & DK & 2 \\
\hline & $\mathrm{BC}$ & 1 & $\mathrm{HI}$ & 2 \\
\hline & $\mathrm{DE}$ & 1 & IN & 1 \\
\hline \multirow[t]{10}{*}{ Europe } & BA & 16 & & \\
\hline & BB & 6 & & \\
\hline & $\mathrm{CD}$ & 5 & & \\
\hline & $\mathrm{AC}$ & 3 & & \\
\hline & $\mathrm{BC}$ & 2 & & \\
\hline & AA & 1 & & \\
\hline & $\mathrm{CB}$ & 1 & & \\
\hline & FC & 1 & & \\
\hline & FF & 1 & & \\
\hline & GF & 1 & & \\
\hline \multirow[t]{5}{*}{ Africa } & BA & 3 & GJ & 4 \\
\hline & $\mathrm{BB}$ & 3 & & \\
\hline & $\mathrm{BC}$ & 3 & & \\
\hline & $\mathrm{CE}$ & 1 & & \\
\hline & EG & 1 & & \\
\hline \multirow[t]{3}{*}{ Asia } & BB & 3 & $\mathrm{GH}$ & 4 \\
\hline & $\mathrm{BC}$ & 1 & EM & 1 \\
\hline & $\mathrm{CD}$ & 1 & GJ & 1 \\
\hline Australia & & & GH & 4 \\
\hline
\end{tabular}


tical. The following two explanations may account for this phenomenon: (i) instability of karyotypes and DNA fingerprints during prolonged cultivation on agar slants, and (ii) replacement of strains. We favor the first option, since instability of karyotypes has been observed in C. neoformans after mutagenesis (2a). Moreover, the rRNA genes occur on the largest chromosomes (54), and differences in the copy number of these genes may result in length polymorphisms as well.

It has been suggested that the karyotypes of saprobic isolates of $C$. neoformans var. gattii vary less than the karyotypes of clinical isolates (26). However, our finding of identical karyotypes and RAPD patterns for three clinical strains of $C$. neoformans var. gattii from India (32) seems to contradict this observation. Although the Asian clinical isolates differ slightly from the Australian Eucalyptus isolates, we do not consider the differences significant.

Different PCR typing strategies may result in detection of different amounts of genetic heterogeneity $(6,8,42,43$; this study). It is evident that RAPD analysis or PCR fingerprinting resolves clusters that, for instance, are not separated by serotyping. Immediate clinical application of the RAPD approach is still controversial, as conflicting results have been obtained when multiple isolates from a single patient have been studied $(7,16)$. There are no generally accepted procedures for interpreting RAPD band patterns. Moreover, using different PCR protocols and/or different primers in different laboratories may result in different results (47-49). It has been suggested that there may be a relationship between isolate characteristics and issues like body location or risk factors for the development of disseminated meningoencephalitis (12). However, Varma et al. (51) challenged these ideas after they encountered comparable genetic diversity in isolates from AIDS patients, non-AIDS patients, and the environment. Our karyotype and RAPD type results are consistent with the latter observation. Therefore, it seems likely that infection is usually acquired by inhalation of saprobically living $C$. neoformans.

Our results suggest that RAPD type BA is dominant in AIDS patients, but this hypothesis may be biased by the sample containing a rather large number of isolates obtained from a local population of AIDS patients (strains RDA 1335 through RDA 4091). Discrimination of all Rotterdam isolates by using PFGE and RAPD analysis was not possible. The relatively homogeneous karyotypes with concordant RAPD patterns, serotypes, and killer types of these isolates suggest that clonal expansion of the fungus occurred in this geographically restricted area, as has been revealed by linkage disequilibrium studies in other areas (6). The observed local genetic homogeneity seems to contradict the results of other studies in which only a very small number of strains was found to be identical when PFGE and DNA fingerprinting were used $(12,36)$. Strains of $C$. neoformans var. neoformans from mastitic cows mainly were serotype D and RAPD type CD organisms, suggesting that there is some degree of genetic differentiation. However, more strains of veterinary origin need to be investigated to settle this issue. Our RAPD data suggest that there is geographical differentiation among populations of $C$. neoformans var. gattii. When previously published DNA fingerprint patterns (51) were compared with strain origins, a comparable geographic pattern was obtained. There seems to be considerable genetic divergence between the Australian and American populations, with the Asian and African populations somewhat intermediate. It has been suggested that this pattern may be correlated with the existence of some geographic and/or genetic substructure in the Eucalyptus hosts (14a).

The following points summarize our results: (i) $C$. neoformans var. neoformans and $C$. neoformans var. gattii differ in genetic makeup and may represent separate species; (ii) no genetic differences were observed among clinical, veterinary, and saprobic isolates of either variety; (iii) both varieties have various numbers of chromosomes and various genome sizes, which probably reflect differences in ploidy and/or aneuploidy; (iv) multiple isolates from a patient may exhibit minor karyotype differences; (v) karyotypes may not be stable after prolonged preservation on agar slants; (vi) RAPD typing data suggest that there is a geographic substructure in $C$. neoformans var. gattii; (vii) isolates from a local population of AIDS patients have relatively homogeneous PFGE and RAPD patterns; and (viii) the combination of PFGE and RAPD analysis is useful in epidemiological research.

\section{ACKNOWLEDGMENTS}

D. H. Ellis (Aidelaide, Australia) is acknowledged for sending some environmental isolates of $C$. neoformans var. gattii. W. van Zanten (Department of Bacteriology, University Hospital Rotterdam, Rotterdam, The Netherlands) assisted with the Gelcompar program, and Debby Tulling, Ilona de Jong, and Marjanne Renting contributed to the karyotype analysis, for which they all are greatly thanked.

\section{REFERENCES}

1. Aulakh, H. S., S. E. Straus, and K. J. Kwon-Chung. 1981. Genetic relatedness of Filobasidiella neoformans (Cryptococcus neoformans) and Filobasidiella bacillispora (Cryptococcus bacillisporus) as determined by deoxyribonucleic acid base composition and sequence homology studies. Int. J. Syst. Bacteriol. 31:97-103.

2. Bennett, J. E., K. J. Kwon-Chung, and T. S. Theodore. 1978. Biochemical differences between serotypes of Cryptococcus neoformans. Sabouraudia 16: $167-174$

2a.Boekhout, T. Unpublished data.

3. Boekhout, T., and G. Scorzetti. Differential killer toxin sensitivity patterns of varieties of Cryptococcus neoformans. J. Med. Vet. Mycol., in press.

4. Boom, R., C. J. A. Sol, M. M. M. Salimans, C. J. Jansen, P. M. E. Wertheimvan Dillen, and J. van de Noordaa. 1990. Rapid and simple method for purification of nucleic acids. J. Clin. Microbiol. 28:495-503.

5. Brandt, M. E., L. C. Hutwagner, R. W. Pinner, and the Cryptococcal Disease Active Surveillance Group. 1995. Comparison of multilocus enzyme electrophoresis and random amplification of polymorphic DNA analysis for molecular subtyping of Cryptococcus neoformans. J. Clin. Microbiol. 33:1890-1895.

6. Brandt, M. E., L. C. Hutwagner, L. A. Klug, W. S. Baughman, D. Rimland, E. A. Graviss, R. J. Hamill, C. Thomas, P. G. Pappas, A. L. Reingold, R. W Pinner, and the Cryptococcal Disease Active Surveillance Group. 1996 Molecular subtype distribution of Cryptococcus neoformans in four areas of the United States. J. Clin. Microbiol. 34:912-917.

7. Casadevall, A., and E. D. Spitzer. 1995. Involvement of multiple Cryptococcus neoformans strains in a single episode of cryptococcosis and reinfection with novel strains in recurrent infection demonstrated by random amplification of polymorphic DNA and DNA fingerprinting. J. Clin. Microbiol. 33: 1682-1683.

8. Chen, S. C. A., A. G. Brownlee, T. C. Sorrell, P. Ruma, D. H. Ellis, T. Pfeiffer, B. R. Speed, and G. Nimmo. 1996. Identification by random amplification of polymorphic DNA of a common molecular type of Cryptococcus neoformans var. neoformans in patients with AIDS or other immunosuppressive conditions. J. Infect. Dis. 173:754-758.

9. Currie, B. P., L. F. Freundlich, and A. Casadevall. 1994. Restriction fragment length polymorphism analysis of Cryptococcus neoformans isolates from environmental (pigeon excreta) and clinical sources in New York City. J. Clin. Microbiol. 32:1188-1192.

10. De Jonge, P., F. C. M. de Jongh, R. Meijers, Y. Steensma, and W. A Scheffers. 1986. Orthogonal-field-alternation gel electrophoresis banding patterns of DNA from yeasts. Yeast 2:193-204.

11. Dromer, F., and J. Charreire. 1991. Improved amphotericin B activity by a monoclonal anti-Cryptococcus neoformans antibody: study during murine cryptococcosis and mechanisms of action. J. Infect. Dis. 163:1114-1120.

12. Dromer, F., A. Varma, O. Ronin, S. Mathoulin, and B. Dupont. 1994. Molecular typing of Cryptococcus neoformans serotype D clinical isolates. J. Clin. Microbiol. 32:2364-2371.

13. Dufait, R., R. Velho, and C. De Vroey. 1987. Rapid identification of the two varieties of Cryptococcus neoformans by D-proline assimilation. Mykosen 30:483.

14. Ellis, D., and T. Pfeiffer. 1992. The ecology of Cryptococcus neoformans. Eur. J. Epidemiol. 8:321-325.

14a.Ellis, D. H. Personal communication.

15. Evans, E. E. 1950. The antigenic composition of Cryptococcus neoformans. I. A serologic classification by means of the capsular and agglutination reactions. J. Immunol. 64:423-430. 
16. Haynes, K. A, D. J. Sullivan, D. C. Coleman, J. C. K. Clarke, R. Emilianus, C. Atkinson, and K. J. Cann. 1995. Involvement of multiple Cryptococcus neoformans strains in a single episode of cryptococcosis and reinfection with novel strains in recurrent infection demonstrated by random amplification of polymorphic DNA and DNA fingerprinting. J. Clin. Microbiol. 33:99-102.

17. Howard, D. H., and K. J. Kwon-Chung. 1995. Zoopathogenic heterobasidiomycetous yeasts. Stud. Mycol. 38:59-66.

18. Ikeda, R., R. Shinoda, Y. Fukuzawa, and L. Kaufman. 1982. Antigenic characterization of Cryptococcus neoformans serotypes and its application to serotyping of clinical isolates. J. Clin. Microbiol. 16:22-29.

19. Kelly, S. L., D. C. Lamb, M. Taylor, A. J Corran, B. C. BaIdwin, and W. G Powderly. 1994. Resistance to amphotericin B associated with defective sterol $\Delta^{8-7}$ isomerase in a Cryptococcus neoformans strain from an AIDS patient. FEMS Microbiol. Lett. 122:39-42.

20. Kluytmans, J., W. van Leeuwen, W. Goessens, R. Hollis, S. Messer, L. Herwaldt, H. Bruining, M. Heck, J. Rost, N. van Leeuwen, A. van Belkum, and H. Verbrugh. 1995. Food-initiated outbreak of methicillin-resistan Staphylococcus aureus analyzed by pheno- and genotyping. J. Clin. Microbiol. 33:1121-1128.

21. Kovacs, J. A., A. A. Kovacs, M. Polis, W. G. Wright, V. J. Gill, C. U. Tuazon, E. P. Gellmann, H. C. Lane, R. Longfield, G. Overturf, A. M. Macher, A. S. Fauci, J. E. Parrillo, J. E. Bennett, and H. Masur. 1985. Cryptococcosis in the acquired immunodeficiency syndrome. Ann. Intern. Med. 103:533-538.

21a.Kwon-Chung, K. J. Personal communication.

22. Kwon-Chung, K. J., and J. E. Bennett. 1984. Epidemiologic differences between the two varieties of Cryptococcus neoformans. Am. J. Epidemiol. 120:123-130.

23. Kwon-Chung, K. J., J. E. Bennett, and T. S. Theodore. 1978. Cryptococcus bacillisporus sp. nov.: serotype B-C of Cryptococcus neoformans. Int. J. Syst. Bacteriol. 28:616-620.

24. Kwon-Chung, K. J., I. Polacheck, and J. E. Bennett. 1982. Improved diagnostic medium for separation of Cryptococcus neoformans var. neoformans (serotypes A and D) and Cryptococcus neoformans var. gattii (serotypes B and C). J. Clin. Microbiol. 15:535-537.

25. Kwon-Chung, K. J., J. E. Bennett, and J. C. Rhodes. 1982. Taxonomic studies on Filobasidiella species and their anamorphs. Antonie van Leeuwenhoek 48:25-38.

26. Kwon-Chung, K. J., B. L. Wickes, L. Stockman, G. D. Roberts, D. Ellis, and D. H. Howard. 1992. Virulence, serotype, and molecular characteristics of environmental strains of Cryptococcus neoformans var. gattii. Infect. Immun. 60:1869-1874.

27. Lazera, M. S., B. Wanke, and N. M. Nishikawa. 1993. Isolation of both varieties of Cryptococcus neoformans from saprophytic sources in the city of Rio de Janeiro, Brazil. J. Med. Vet. Mycol. 31:449-454.

28. Levitz, S. M. 1991. The ecology of Cryptococcus neoformans and the epidemiology of cryptococcosis. Rev. Infect. Dis. 13:1163-1169.

29. Meyer, W., T. G. Mitchell, E. Freedman, and R. Vilgalys. 1993. Hybridization probes for conventional DNA fingerprinting used as single primers in the polymerase chain reaction to distinguish strains of Cryptococcus neoformans. J. Clin. Microbiol. 31:2274-2280.

30. Mitchell, T. G., and J. R. Perfect. 1995. Cryptococcosis in the era of AIDS100 years after the discovery of Cryptococcus neoformans. Clin. Microbiol. Rev. 8:515-548.

31. Mukaramangwa, P. 1995. Apport de l'étude de Cryptococcus neoformans à l'épidémiologie de la cryptococcose. Ph.D. thesis. University of Antwerp, Antwerp, Belgium.

32. Padhye, A. A., A. Chakrabarti, J. Chander, and L. Kaufman. 1993. Cryptococcus neoformans var. gattii in India. J. Med. Vet. Mycol. 31:165-168.

33. Paugam, A., J. Dupouy-Camet, P. Blanche, and J. P. Gangneux. 1994. Increased fluconazole resistance of Cryptococcus neoformans isolated from a patient with AIDS and recurrent meningitis. Clin. Infect. Dis. 19:975-976.

34. Peetermans, W., H. Bobbaers, J. Verhaegen, and J. Vandepitte. 1993. Fluconazole resistant Cryptococcus neoformans var. gattii in an AIDS patient. Acta Clin. Belg. 48:405-409.

35. Perfect, J. R., B. B. Magee, and P. T. Magee. 1989. Separation of chromo- somes of Cryptococcus neoformans by pulsed-field gel electrophoresis. Infect. Immun. 57:2624-2627.

36. Perfect, J. R., N. Ketabchi, G. M. Cox, C. W. Ingram, and L. Beiser. 1993 Karyotyping of Cryptococcus neoformans as an epidemiological tool. J. Clin. Microbiol. 31:3305-3309.

37. Pfeiffer, T. J., and D. H. Ellis. 1993. Serotypes of Australian environmental and clinical isolates of Cryptococcus neoformans. J. Med. Vet. Mycol. 31: 401-404.

38. Polacheck, I., and K. J. Kwon-Chung. 1980. Creatinine metabolism in Cryptococcus neoformans and Cryptococcus bacillisporus. J. Bacteriol. 142:15-20.

39. Polacheck, I., and G. A. Lebens. 1989. Electrophoretic karyotype of the pathogenic yeast Cryptococcus neoformans. J. Gen. Microbiol. 135:65-71.

40. Reblin, T., A. Meyer, H. Albrecht, and H. Greten. 1994. Disseminated cryptococcosis in a patient with AIDS. Mykosen 37:275-279.

41. Schmeding, K. A., S. C. Jong, and R. Hugh. 1981. Sexual compatibility between serotypes of Filobasidiella neoformans (Cryptococcus neoformans). Curr. Microbiol. 5:133-138.

42. Sorrell, T. C., A. G. Brownlee, P. Ruma, R. Malik, T. J. Pfeiffer, and D. H. Ellis. 1996. Natural environmental sources of Cryptococcus neoformans var. gattii. J. Clin. Microbiol. 34:1261-1263.

43. Sorrell, T. C., S. C. A. Chen, P. Ruma, W. Meyer, T. J. Pfeiffer, D. H. Ellis and A. G. Brownlee. 1996. Concordance of clinical and environmental isolates of Cryptococcus neoformans var. gattii by random amplification of polymorphic DNA analysis and PCR fingerprinting. J. Clin. Microbiol. 34:12531260 .

44. Spitzer, E. D., and S. G. Spitzer. 1992. Use of a dispersed repetitive DNA element to distinguish clinical isolates of Cryptococcus neoformans. J. Clin. Microbiol. 30:1094-1097.

45. Swinne, D. 1984. Study of Cryptococcus neoformans varieties. Mykosen 27: $137-141$

46. Swinne-Desgain, D. 1975. Cryptococcus neoformans of saprophytic origin Sabouraudia 13:303-308.

47. van Belkum, A. 1994. DNA fingerprinting of medically important microorganisms by use of PCR. Clin. Microbiol. Rev. 7:174-184.

48. van Belkum, A., R. Bax, P. Peerbooms, W. Goessens, N. van Leeuwen, and W. Quint. 1993. Comparison of phage typing and DNA fingerprinting by polymerase chain reaction for discrimination of methicillin-resistant Staphylococcus aureus strains. J. Clin. Microbiol. 31:798-803.

49. van Belkum, A., J. Kluytmans, W. van Leeuwen, R. Bax, W. Quint, E. Peters, A. Fluit, C. Vandenbroucke-Grauls, A. van den Brule, H. Koeleman, W. Melchers, J. Meis, A. Elaichouni, M. Vaneecboutte, F. Moonens, N. Maes, M. Struelens, F. Tenover, and H. Verbrugh. 1995. Multicenter evaluation of arbitrarily primed PCR for typing of Staphylococcus aureus strains. J. Clin. Microbiol. 33:1537-1547.

50. Varma, A., and K. J. Kwon-Chung. 1992. DNA probe for strain typing of Cryptococcus neoformans. J. Clin. Microbiol. 30:2960-2967.

51. Varma, A., D. Swinne, F. Staib, J. E. Bennett, and K. J. Kwon-Chung. 1995 Diversity of DNA fingerprints in Cryptococcus neoformans. J. Clin. Microbiol. 33:1807-1814.

52. Versalovic, J., T. Koeuth, and J. R. Lupski. 1991. Distribution of repetitive DNA sequences in eubacteria and application to fingerprinting of bacterial genomes. Nucleic Acids Res. 19:6823-6831.

53. Vilgalys, R., and M. Hester. 1990. Rapid genetic identification and mapping of enzymatically amplified ribosomal DNA from several Cryptococcus species. J. Bacteriol. 172:4238-4246.

54. Wickes, B. L., T. D. E. Moore, and K. J. Kwon-Chung. 1994. Comparison of the electrophoretic karyotypes and chromosomal location of ten genes in the two varieties of Cryptococcus neoformans. Microbiology 140:543-550.

55. Wilson, D. E., J. E. Bennett, and J. W. Bailey. 1968. Serologic grouping of Cryptococcus neoformans. Proc. Soc. Exp. Biol. Microbiol. 127:820-823.

56. Yamamoto, Y., S. Kohno, H. Koga, H. Kakeya, K. Tomono, M. Kaku, T Yamazaki, M. Arisawa, and K. Hara. 1995. Random amplified polymorphic DNA analysis of clinically and environmentally isolated Cryptococcus neoformans in Nagasaki. J. Clin. Microbiol. 33:3328-3332. 